Environmental Radioactivity

Elsevier Editorial system(tm) for Journal of Manuscript Draft

Manuscript Number: JENVRAD-D-15-00668R1

Title: SPANISH EXPERIENCE ON THE DESIGN OF RADON SURVEYS BASED ON THE USE OF GEOGENIC INFORMATION

Article Type: SI: Geogenic Radon

Keywords: Key words: Radon mapping; Spain; Geology; Lithoestratigraphy; Lithology

Corresponding Author: Ms. Alicia Fernández Villar,

Corresponding Author's Institution:

First Author: Carlos Sainz Fernandez, Prof

Order of Authors: Carlos Sainz Fernandez, Prof; Luis Santiago Quindos Poncela, Prof; Alicia Fernández Villar; Ismael Fuente Merino, PhD ; Jose Luis Gutierrez Villanueva, PhD; Santiago Celaya Gonzalez, PhD ; Luis Quindos Lopez; Jorge Quindos Lopez; Enrique Fernandez Lopez; Juan Remondo Tejerina; Jose Luis Martin Matarranz; Marta Garcia Talavera

Abstract: One of the requirements of the recently approved EU-BSS (European Union Basic Safety Standards) is the design and implementation of national radon action plans in the member states (Annex XVIII). Such plans require radon surveys. The analysis of indoor radon data is supported by the existing knowledge about geogenic radiation. With this aim, we used the terrestrial gamma dose rate data from the MARNA project. In addition, we considered other criterion regarding the surface of Spain, population, permeability of rocks, uranium and radium contain in soils because currently no data are available related to soil radon gas concentration and permeability in Spain. Given that, a Spanish radon map was produced which will be part of the European Indoor Radon Map and a component of the European Atlas of Natural Radiation. The map indicates geographical areas with high probability of finding high indoor radon concentrations. This information will support legislation regarding prevention of radon entry both in dwellings and workplaces. In addition, the map will serve as a tool for the development of strategies at all levels: individual dwellings, local, regional and national administration. 


\section{SPANISH EXPERIENCE ON THE DESIGN OF RADON SURVEYS BASED ON THE USE OF}

\section{GEOGENIC INFORMATION}

3

4 C. Sainz Fernández ${ }^{1}$, L.S. Quindós Poncela ${ }^{1}$, A. Fernández Villar ${ }^{* 1}$, I. Fuente Merino ${ }^{1}$, J.L.

5 Gutierrez-Villanueva1', S. Celaya González¹, L. Quindós López¹, J. Quindós López¹, E. Fernández¹, 6 J. Remondo Tejerina², J.L. Martín Matarranz ${ }^{3}$, M. García Talavera ${ }^{3}$

7

$8{ }^{1}$ Radon Group. University of Cantabria. C/Cardenal Herrera Oria s/n 39011, Santander, Spain

$9{ }^{2}$ CITIMAC. University of Cantabria. Avda.de los Castros s/n 39005, Santander, Spain

$10{ }^{3}$ Nuclear Safety Council. C/Justo Dorado 11 28040, Madrid, Spain

11

12 *Corresponding author: fernandezva@unican.es

13 
${ }^{*}$ Highlights (for review)

1 Highlights

2 The last version of the Spanish indoor radon map accounts with 9,211 measurements.

3 Several criteria has been designed to plan a measurements campaign based on known 4 correlations.

5 Lithostratigraphy is a good criterion for radon mapping (national scale). Local scales need others.

6 


\section{INTRODUCTION}

2 The design of the Spanish indoor radon map is part of the framework of the European Commission's 3 plan for the elaboration of the European Indoor Radon map, as a part of the European Natural 4 Radiation Atlas (Dubois et al., 2010; Tollefsen et al., 2011; JRC_REM_EC, 2014; JRC_IES, 2012).

5 This atlas will support policies in the field of public health, and it will contribute to increase the 6 general public's awareness of the annual dose due to natural radioactivity.

7

$8 \mathrm{~A}$ number of studies in various countries have proved that there is a clear correlation between 9 exposure to radon inside buildings and the risk of developing lung cancer (ICRP 2010, 2011). Radon 10 gas is responsible for between 3 and 4 per cent of deaths caused by this illness in the first world 11 (IAEA, 2011; WHO, 2009), being the main source of ionizing radiation (EURATOM 1990, 1996, 2013; 12 ICRP, 1994). Therefore, it is crucial to determine the areas where there is a greater probability of 13 finding buildings with higher radon concentrations, as well as to analyse the variables which affect 14 radon concentrations inside buildings.

16 Indoor radon concentration varies geographically. This is due to the large number of factors that 17 affect radon appearance in buildings, such as the geology of the areas upon which buildings are 18 constructed, soil permeability, specific rock characteristics, the meteorology and topography of the 19 region, the proximity of active fault lines, the materials employed in construction, the design features 20 of the buildings and the lifestyle habits of the occupants (García et al., 2013a). In our work we used 21 a geographic information system (GIS) which enabled us to capture, store, create searches, analyse 22 and visualize the statistical data we obtained. In order to adapt to the design of the European Indoor 23 Radon map, Spain followed national (CSN 2012a; CSN 2012b) and international legislation (ICRP 24 1993, 2009, 2014).

26 This paper aims to produce a radon map of the Spanish territory that shows the probability of finding 27 areas with levels of radon indoors, and is related to the European legislation that has to be 28 implemented in the member states before the end of 2018 (EURATOM 2013). This map will be a 29 very useful instrument for applying the requirements of European legislation on the radon issue at all 30 administrative levels: national, regional and local. 


\subsection{Definition of the grid}

36

37 The grid was generated using the programme ArcGIS where the extreme corners are defined by 38 established coordinates as such by the EC in the European Datum 1950 UTM Zone 30N (ED50) 39 projection system: Peninsular Spain NW $(433193,87$; 4834808,73) SE $(692906,43$; 3961069,60) 40 Canary Islands NW $(692915,11 ; 3320469,29)$ SE $(698454,23 ; 2988008,14)$. These coordinates 41 were converted to longitude-latitude ED50 (decimal degrees) to generate a $10 \times 10 \mathrm{~km}^{2}$ grid of the 42 Spanish surface in Google Earth format (.kml). The ED50 system is an old geodetic reference 43 system used in Europe and has been used in coexistence with the ETRS89 in Spain until 2015. The 44 parameters of this system are defined in the ArcGIS as shown in Table 1.

45 In order to follow a similar scheme as other EU member countries, we began working with a 46 continental level projection system (GISCO-Lambert Acimutal Equal Area) following the guidelines 47 established by the EC (Dubois et al., 2010; Tollefsen et al., 2014). The Lambert Azimuthal Equal 48 Area projection is a planar projection, which means that map data are projected onto a flat surface.

49 In this way, measurements between countries can homogenized and the so call border effect 50 avoided. Table 1 shows the parameters used to convert ED50 to GISCO-LAEA ArcGIS. As we show 51 in Table 1, we took into account those parameters set by the EC. Therefore we obtain the following 52 limits for $10 \times 10 \mathrm{~km}^{2}$ grid: Peninsular Spain NW ( -1500000; -301000) SE (-351000; -1350000) 53 Canary Islands NW (-2700000; -1900000) SE (-2150000; -1650000).

54

55 To define the working area, we used the administrative boundaries provided by the National 56 Geographic Institute (IGN, 2014). Thus we generated a total number of 5,478 cells of $10 \times 10 \mathrm{~km}^{2}$ 57 surface. For each cell, an identifying code was created and its centroid in meters (" $x$ " and " $y$ " 58 coordinates) calculated. The statistical data obtained from the measurements were georeferenced to 59 the centroid.

60

61

\subsection{The measurement campaigns}

62 The Spanish indoor radon map comprises, to date, 9,211 measurements, obtained over successive 63 sampling campaigns (Figure 1). In each campaign, a series of measurements for each cell was 64 defined, taking into account superficial, population, external gamma dose (MARNA Project) (Sainz et 65 al., 2014; Suárez et al., 1997, 2000; Quindós et al., 2004, 2008) and lithostratigraphic criteria. To 66 decide the number of measurements per cell, it was essential to prioritise objectives and establish 
67 criteria. The decision on which criteria to use was made taking into account the objectives behind the 68 European Radon map.

69

70 1. Surface criterion: The whole Spanish territory had to be covered by, at least one measurement per $7110 \times 10 \mathrm{~km}$ grid cell. 478 cells out of 5,478 total number of cells are inhabited and no data were 72 collected. Thus, the lowest number of possible measurements was done over 5,000 cells.

73

74 2. Population criterion: In the first measurement campaign, an extra measurement was done for each 75 town with a population exceeding 50,000 inhabitants, based on the Spanish National Statistics 76 Institute (INE, 2014). Hence, an additional 1,000 measurements had to be made according to this 77 criterion. In the second campaign this criterion was expanded to require a minimum of 6 78 measurements in cells including towns with populations larger than 200,000. A further 123 79 measurements were taken to meet this criterion.

81 3. MARNA criterion: Considering the importance of the geological factor it was decided to increase 82 the number of measurements in areas with high radon potential. The starting point was the MARNA 83 project (Suárez et al., 2000). MARNA determines potential radon emissions by taking into account 84 the correlation between ${ }^{226} \mathrm{Ra}$ concentration in the soil and outdoor gamma dose levels.

85 This criterion is based from 7,400 locations where measurements were performed to determine the 86 potential for radon emission. These locations were linked to the $10 \times 10 \mathrm{~km}^{2}$ cells, so-called MARNA 87 cells. The different levels of exposure assigned to each cell correspond to the town with the higher 88 dose. During the first campaign, additional measurements were taken in each cell identified in the 89 MARNA project with a gamma exposure level over $35 \mathrm{nGy} / \mathrm{h}$ [4 $\mu \mathrm{R} / \mathrm{h}]$. 2 additional measurements 90 were added for each location that exceeded $35 \mathrm{nGy} / \mathrm{h}[4 \mu \mathrm{R} / \mathrm{h}]$.

91 By doing so, 2,000 additional measurements were made (Sainz et al., 2014). Throughout the second 92 campaign, measurements focused on towns with a gamma exposure level between 65 and 122 $93 \mathrm{nGy} / \mathrm{h}[7.5$ and $14 \mu \mathrm{R} / \mathrm{h}$ ] (median risk) and involved a minimum of 6 measurements for each cell with 94 this dose criterion. In the whole territory, 1,655 MARNA cells of this type were found, but the number 95 of measurements taken was reduced to 960 due to limitations in budget.

96 The towns were classified according to their highest dose starting from $122 \mathrm{nGy} / \mathrm{h}$ and arranged in a 97 decreasing order. A selection was made from the highest doses adjusted to the requirement of 6 98 measurements per cell, obtaining 960 measures. The result was the implementation of the measures 99 in cells between 104 and 122 nGy/h [12 and $14 \mu \mathrm{R} / \mathrm{h}$ ]. 
1014 . Lithostratigraphic criterion: Numerous studies support the importance of soil permeability factor in 102 determining the radon potential in buildings (Kemski et al., 2001). Permeability is part of the 103 lithological nature of the rock. The proper way to map this feature is by means of the lithostratigraphic 104 map. It represents the lithostratigraphy homogeneously grouped by similar levels mapping 105 permeability values (Garcia et al.,2013b).

106 Following the European Commission's guidelines (JRC-EC, 2014; JRC_REM_EC, 2014; JRC-IES, 107 2012) towards designing a European wide geological radon map, a series of areas of interest were 108 identified in accordance with lithostratigraphic units for different regions and with that a specification 109 of the number of measurements to be taken per unit and town (see Tables 2 and 3). The grouping of 110 lithostratigraphies into units and regions of interest was due to the need of complying with the 111 European Commission's premises for accounting for the permeability of the soils upon which 112 buildings are constructed (Tollefsen et al., 2014).

113 By using the lithostratigraphic map from Geological and Mining Institute of Spain (IGME, 2014a; 114 IGME, 2014b) at 1:200,000 scale, which includes the permeability factor of lithological units, units of 115 interest were identified and cross checked with the local and regional cartographic databases (IGN, 116 2014). This increased the number of towns where measurements were to be taken. In order to 117 identify the cells affected by this criterion, the above mentioned towns were superimposed onto the $11810 \times 10 \mathrm{~km}$ cell base and an additional 270 measurements were done. Figures 2 and 3 show the 119 implementation of the previous criteria during the two measuring campaigns.

\subsection{Radon measurements}

122 The measurements were carried out using CR-39 track-etch detectors over an exposure period of 3 123 to 6 months. Having identified the sample cells, houses were selected in different ways. Random 124 locations within the cell were selected and local institutions and government agencies were 125 approached by telephone in most cases.

126 Each detector was distributed together with installation instructions, a form to be filled up, an 127 information CD, some explanatory letters and a postage-paid envelope for returns. The form included 128 questions regarding the building's design, building materials and occupants' lifestyle patterns.

129 The radioactivity laboratory of University of Cantabria (LaRUC) is validated to carry out these types 130 of measurements under the validation scheme designed by PHE (Public Health England, UK) every 131 year. Additionally, the laboratory evaluates the quality of the detector calibration by means of inter132 comparison exercises at national and international levels on a regular basis (Gutierrez-Villanueva, $1332011,2015)$. 
135 The measurements took place in ground-level buildings following the protocol of placing the detector 136 in the main room at a height between 1 and $2 \mathrm{~m}$ on a shelf or wardrobe separate from the wall, and 137 always away from air currents and heat sources. Once the measurement had been taken, a report 138 was sent to the collaborator informing of the radon level in the buildings and including 139 recommendations in order to reduce the concentration if it were deemed high.

\subsection{Data representation}

142 The measurement data were stored using the Geographic Information System's database including: 143 identifying code of each detector; the result of the measurement (in $\mathrm{Bq} / \mathrm{m}^{3}$ ); location where the 144 measurement was made; " $x$ " and " $y$ " coordinates and the cell of the location; and detector exposure 145 time. Thence, the following data were obtained for each cell: number of measurements; geometric 146 mean; arithmetic mean; median; minimum and maximum values and standard deviations. Their 147 graphic representation was achieved by assigning these data to the " $x$ " and " $y$ " coordinates of the 148 centroids of each cell. By doing so we ensured the anonymity of the project's collaborators, as the 149 original data regarding the exact locations of the buildings were not shown on the map (Figure 4).

\section{RESULTS}

152

153 The Spanish indoor radon map now includes a total number of 9,211 measurements distributed 154 across the country. The data conform to a log-normal distribution (Figure 5), as is commonly found 155 when dealing with radon. The geometric mean and geometric standard deviation are the parameters 156 often used to characterize this type of distribution.

158 The final result is the map shown in Figure 6. The cells with 1 measure were represented by the 159 value of radon concentration obtained. The cells with a number of measurements between 2 and 5 160 were represented by using the arithmetic mean, and the cells with more than 6 radon measurements 161 used the geometric mean.

162 The classification was carried out into four categories: $<50,50-100,100-300$ and $>300 \mathrm{~Bq} / \mathrm{m}^{3}$, in 163 compliance with recommendations of the World Health Organization (WHO, 2009), the International 164 Commission on Radiological Protection (ICRP, 2009, 2014) and the Nuclear Safety Council (CSN, 165 2012a) which establish the reference levels in the range 100 and $300 \mathrm{~Bq} / \mathrm{m}^{3}$. Among the Spanish 166 data, $12 \%$ of the cells were in this range and $1 \%$ had geometric means higher than $300 \mathrm{~Bq} / \mathrm{m}^{3}$. This 167 means that a large proportion of Spain's surface surpasses the limits recommended by international 168 institutions and the national authority (table 4) 
170 The majority of the Spanish territory is now covered by at least one measurement (Figure 8 and table

1715 ), but there are areas with few measurements (between 1 and 5 measures, $52 \%$ of the surface).

172 Incomplete cells (41\%) are the result of not being able to carry out a complete analysis in successive 173 sampling campaigns (inside this category $6 \%$ of the cells is included without population). Whereas $1747 \%$ of the surface has had greater than 6 measurements. This density of measures by cell is 175 explained in the own criteria of sampling of the project.

176 Given that a part of the national territory is covered by only one measure, singular points with high 177 concentration have been found in non prone areas. The significance of the values associated to 178 these cells will increase with a higher number of measurements in future campaigns.

179 Table 6 shows a summary of the overall statistics of the data. As we can see, in comparison with 180 previous measurement campaigns (CSN, 1998; Martín Matarranz, J.L, 2004; García et al., 2013a; 181 Sainz et al., 2014), both the national geometric and the arithmetic mean have increased. This is due 182 to the fact that in this second phase of the project the focus has been upon areas expected to have 183 high radon exposure.

184

185 An interesting aspect is that areas with a high radon exposure were selected in accordance with 186 lithostratigraphic criterion instead of lithologic or geologic criteria. The first criterion takes into account 187 the soil permeability. Lithological maps show the most representative lithologic associations and 188 geological maps show chronolithostratigraphic units (IGME, 2014b). The use of the lithostratigraphic 189 map is justified by the fact that it incorporates the lithologic permeability factor, which is of great 190 interest when analysing the behaviour of radon. Additionally, it represents units in a smaller scale 191 and, consequently, in greater detail than the geologic or lithologic maps used up until now.

193 Previous studies have use lithostratigraphy to identify high radon areas in Spain (Garcia et al., $1942013 b)$. To test whether this criterion is valid or not, we investigated if it is possible to identify cells 195 with radon concentrations higher than $300 \mathrm{~Bq} / \mathrm{m}^{3}$ and in the range $100-300 \mathrm{~Bq} / \mathrm{m}^{3}$.

196

197 In order to verify the validity of lithostratigraphic criterion, 40 units identified as radon prone areas 198 were selected and compared with available measurements in those areas. By overlapping the 42 199 cells over $300 \mathrm{~Bq} / \mathrm{m}^{3}$ with the above mentioned units, it was found that $88 \%$ of these cells were 200 included within these areas. In the same way, the comparison of the 602 cells with a range of 201 between 100 and $300 \mathrm{~Bq} / \mathrm{m}^{3}$, led to a $70 \%$ of agreement (see Figure 7 and Table 7). 
202 The reason to find cells out of the mentioned comparison might be due to the different factors 203 involved with high radon concentrations indoors (building materials, geological faults, ventilation 204 rates, etc.). So it is necessary to perform extra measurements in those cells located in radon prone 205 areas to validate the preliminary results. This would confirm the importance of lithostratigraphy to 206 identify areas with high radon levels.

207

208

\section{CONCLUSIONS}

209 We have used different approaches to find areas with high radon concentrations: lithostratigraphy, 210 lithology and geology. We conclude that the lithostratigraphy is most useful since it includes the soil 211 permeability as a parameter, which is one of the keys to explain the radon transport in the soil.

212 However, our study revealed that some of the high radon zones cannot be related to 213 lithostratigraphical units. Therefore we need to increase the effort on gathering more radon data in 214 order to generate a map that shows homogeneous geological units that may be identified as 215 potential radon risk areas. The lithostratigraphical classification is sufficient to a national scale but 216 questionable when we want to go into more local scales.

218 Despite the fact that the number of measurements in Spain has increased with the latest sampling 219 campaigns, we have realised that that there are areas where the number of measurements remains 220 low. Future campaigns should be focus on those areas with not enough radon measurements, as 221 well as in those cells where high radon values have been found without correlation with 222 lithostratigraphic classification.

223 We are going to develop probabilistic models of indoor radon presence to identify high radon risk 224 areas on the basis of geologically similar units where the amount of measurements is lower. Also, in 225 the future this model will enable us to verify the correlation between the different geographic 226 variables in order to identify those which bring about the presence of higher concentrations to a 227 greater extent.

\section{8 \\ 5. ACKNOWLEDGEMENTS}

229 Authors express their gratitude to the Spanish Nuclear Safety Council that made possible the 230 national measurement campaigns through different agreements. The authors would also like to thank 231 the staff at the LaRUC laboratory for their invaluable help and cooperation during this study. 
233 CSN. 1998. Measures of radon in Spanish homes. Collection other documents 6.1998. ISBN 84234 87275-76-1. Online at:

235 https://www.csn.es/images/stories/publicaciones/unitarias/otros_documentos/ode-04.02_radon.pdf 236

237 CSN. 2012a. Safety guide 11.02. Control of exposure to natural sources of radiation. Online at:

$238 \mathrm{https} / / / w w w . c s n . e s / i m a g e s /$ stories/publicaciones/unitarias/guias_seguridad/gs-11-02ok.pdf

239

240 CSN. 2012b. Instruction IS -33. Radiological criteria from exposure to natural radiation. BOE n-22.

24126 of January. Online at: https://www.csn.es/documents/10182/27596/

242

243 Dubois, G., Bossewb, P., Tollefsena, T. and De Cort, M. 2010. First steps towards a European atlas 244 of natural radiation: status of the European indoor radon map. Journal of Environment Radioactivity.

245 101, pp 786-798.

246

247 EURATOM. 1990. Commission recommendation of 21February 1990 on the protection of the public

248 against indoor exposure to radon. 90/143/Euratom. European Commission.

249

250 EURATOM. 1996. Council directive 96/29/Euratom of 13 May 1996, laying down basic safety

251 standards for the protection of health of workers and the general public against the danger arising

252 from ionizing radiation. Off. J. European Commission. No. L159.

253

254 EURATOM. 2013. Council Directive (2013/59/Euratom) on basic safety standards for protection 255 against the dangers arising from exposure to ionising radiation.

256

257 García Talavera, M., Matarranz, J.L., Gil, R., García, J.P., Suárez, E. 2013a. Predictive map of 258 exposure to radon in Spain. CSN. Ref: INT-04.31

259

260 García Talavera, M., García Pérez, A.; Rey, C.; Ramos, L.; 2013b. Mapping radon-prone areas

261 using radiation dose rate and geological information. Journal of Radiological Protection. 33, pp 605-

262 620. Online at:

263 stacks.iop.org/JRP/33/605

264

265 Gutierrez-Villanueva, J.L., Sainz Fernández, C., Fuente Merino, I., Quindós López, L., Quindós

266 López, J., Fernández Villar, A.,Casal Ordas, S.E., López Abascal, D., Arteche Laso, D., Fernández

267 López, E., Quindós Poncela, L.S., International Intercomparasion Exercise on Natural Radiation

268 Measurements under Field Conditions. 2011 .ISBN 9788486116644

269

270 Gutierrez-Villanueva, J.L., Sainz Fernández, C., Fuente Merino, I., Celaya González, S., Quindós

271 López, L., Quindós López, J., Fernández Villar, A.,Casal Ordas, S.E., López Abascal, D., Arteche

272 Laso, D., Fernández López, E., Quindós Poncela, L.S., Inter-Laboratory Comparison on Indoor

273 Radon Measurements under Field Condictions. 2015 .ISBN 9788486116910

274

275 IAEA. 2011. Radiation Protection and Safety of Radiation Sources: International Basic Safety

276 Standards - Interim Edition. General Safety Requirements Part 3. ISBN:978-92-0-120910-8

277

278 ICRP, 1993. Protection against radon-222 at home and at work. ICRP. Publication 65. Ann. ICRP 23.

279

280 ICRP, 1994. Human respiratory tract 1532 model for radiological protection. ICRP Publication 66. 281 Ann. ICRP 24.

282

283 ICRP, 2009. ICRP Statement on Radon. (ICRP/Ref 00/902/09)

284

285 ICRP, 2010. Lung cancer risk from radon and progeny. ICRP Publication 115, Part 1, Ann. ICRP 40.

286

287 ICRP, 2011. ICRP Draft report for consultation. Ref 4829-9671-6554. 
289 ICRP, 2014. Radiological Protection against Radon Exposure. ICRP Publication 126. Ann. ICRP 43 290

291 Kemski J, Siehl A, Stegemann R and Valdivia-Manchego M .2001. Mapping the geogenic radon 292 potential in Germany. Sci. Total Environ.

293

294 Martín Matarranz, J.L.,2004. Concentrations of radon in Spanish homes. Other studies of natural 295 radiation. Technical reports collection. CSN.

296

297 Quindos, L. S., Fernandez, P. L., Gomez Arozamena, J.,Sainz, C., Fernandez, J. A., Suarez Mahou, 298 E., Martin,Matarranz, J. L. and Cascon, M. C. 2004. Natural gamma radiation map (MARNA) and 299 indoor radon levels in Spain. Environ. Int. 29.

300

301 Quindós, L.S., Fernández, P.L., Sainz, C., Fuente, I., Nicolás, J. Quindós,L., Arteche, J.,. 2008.

302 Indoor radon in a Spanish region with different gamma exposure levels. Journal of Environmental

303 Radioactivity

304

305 Sainz Fernández, C., Fernández Villar, A., Fuente Merino, I., Gutierrez-Villanueva, J.L., Martin

306 Matarranz, J.L., Garcia Talavera, M., Casal Ordas, S., and Quindós Poncela, L.S.,. 2014. The

307 Spanish indoor radón mapping Strategy.Radiation Protection Dosimetry. 162, Issue 1-2, pp 58-62. 308

309 Suarez Mahou, E. and Fernandez, J. A. 1997. Project MARNA: natural gamma radiation map.

310

311 Suárez Mahou, E, Fernández Amigot, J.A, Baeza Espasa, A, Moro Benito, M.C, Garcia Pomar, D,

312 Moreno del Pozo, J, Lanaja del Busto, J.M. 2000. Marna Project. Map of natural gamma radiation.

313 Technical reports collection. CSN.

314

315 Tollefsen, T., Gruber, V., Bossew, P. and De Cort, M. 2011. Status of the European indoor radon

316 map. Radiation Protection Dosimetry. 145.

317

318 Tollefsen, E, Cinelli, G, Bossew, P, Gruber, V, and De Cort, M. 2014. From the European Indoor

319 Radon Map towards and Atlas of Natural Radiation. Radiation Protection Dosimetry 162, No. 1-2,

321 WHO. 2009. WHO Handbook on Indoor Radon: A Public Health Perspective, WHO, ISBN 978924

3221547673.

323

324 Web references

325

326 IGME. 2014a. Geological and Mining Institute of Spain

327 http://mapas.igme.es/Servicios/default.aspx\#IGME_Litoestratigrafico200

328

329 IGME. 2014b. Geological and Mining Institute of Spain

$330 \mathrm{http}: / /$ info.igme.es/cartografia/oneGeology.asp?mapa=oneGeologyEuropa

331

332 IGN. 2014. Spanish National Geographic Institute

$333 \mathrm{http}: / /$ centrodedescargas.cnig.es/CentroDescargas/equipamiento.do;jsessionid=C2800EC111853C3

334 AF346D382336BB450?method=mostrarEquipamiento

335

336 INE. 2014. Spanish National Institute of Statics

$337 \mathrm{http}: / /$ www.ine.es/nomen2/index.do?accion=busquedaRapida\&subaccion=\&numPag=0\&ordenAnios

338 =ASC\&nombrePoblacion=huesa\%2Bdel\%2Bcom\%FAn\&botonBusquedaRapida=Consultar\%2Bsele $339 \mathrm{cci} \% \mathrm{~F} 3 \mathrm{n}$

340

341 JRC-IES.2012. Ispra, Italy. A first version of a European Geogenic Radon Map (EGRM). Symposium 342 and workshop,

343 http://www.radon.eu/workshop2012/pres/03gruber_egrm_praesforwebpage.pdf 
345 JRC-EC, 2014

346 https://ec.europa.eu/jrc/en/search/site/maps?f[0]=im_field_research_areas\%3A17

347

348 JRC-REM-EC,2014

349 https://rem.jrc.ec.europa.eu/RemWeb/

350

351 


\section{FIGURE CAPTIONS}

2

3 Figure 1: Description of the sampling campaigns carried out towards the development of the 4 Spanish indoor radon map

5

6 Figure 2: Schematic view of the criteria used in the first campaign resulting in 8,000 measurements 7

8 Figure 3: Extension of measurements to create the Spanish indoor radon map by including 9 additional criteria: surface, lithostratigraphy and MARNA

10

11 Figure 4: Process used to incorporate the results of the measurements into the Geographic 12 Information System (GIS)

13

14 Figure 5: Log-normal distribution of the current data included in the Spanish indoor radon map.

15 Values of geometric mean (GM) and arithmetic mean (AM) are expressed in $\mathrm{Bq} / \mathrm{m}^{3}$. 16

17 Figure 6: The Spanish indoor radon map up-to-date. The cells include a total number of 9,211 radon 18 determinations.

19

20 Figure 7: Lithoestratigraphic units identified as radon prone areas and cells with high radon 21 concentration

22

23 Figure 8: Graphical view of the situation of the cells in terms of the number of data included in each 24 cell.

25

26 


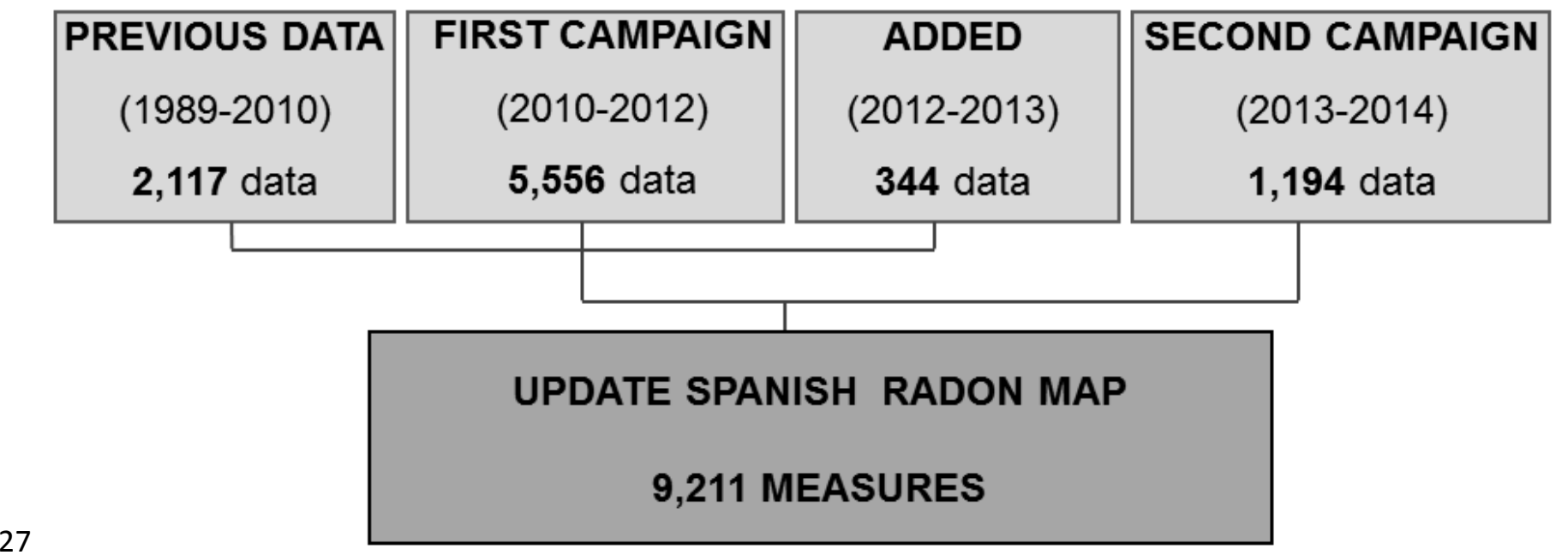

28 Figure 1

29

30

31

32

33

34

35

36

37

38

39

40

41

42

43

44

45

46 


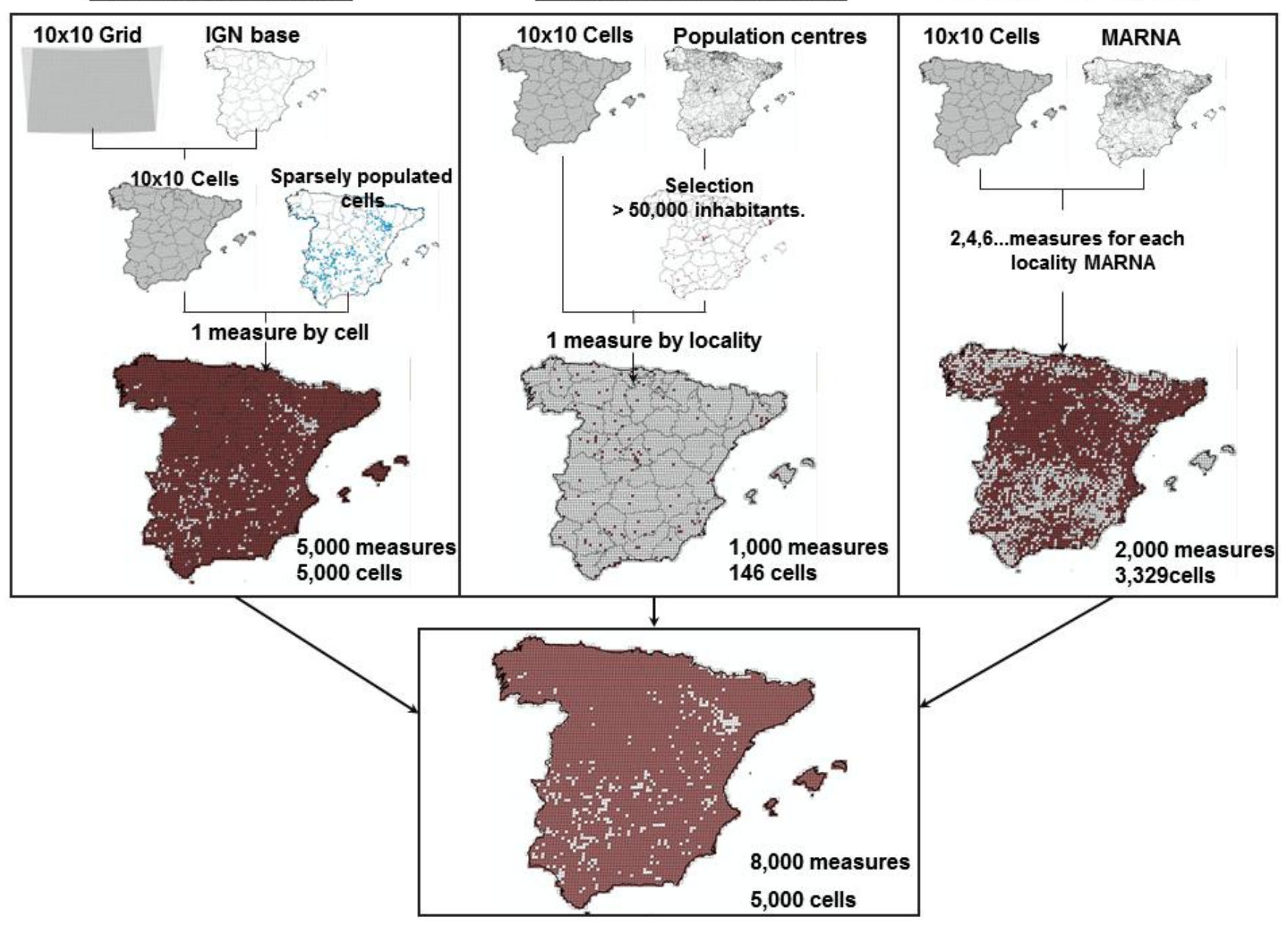

48 Figure 2 
Surface Criterion Lithostratigraphy Criterion MARNA Criterion

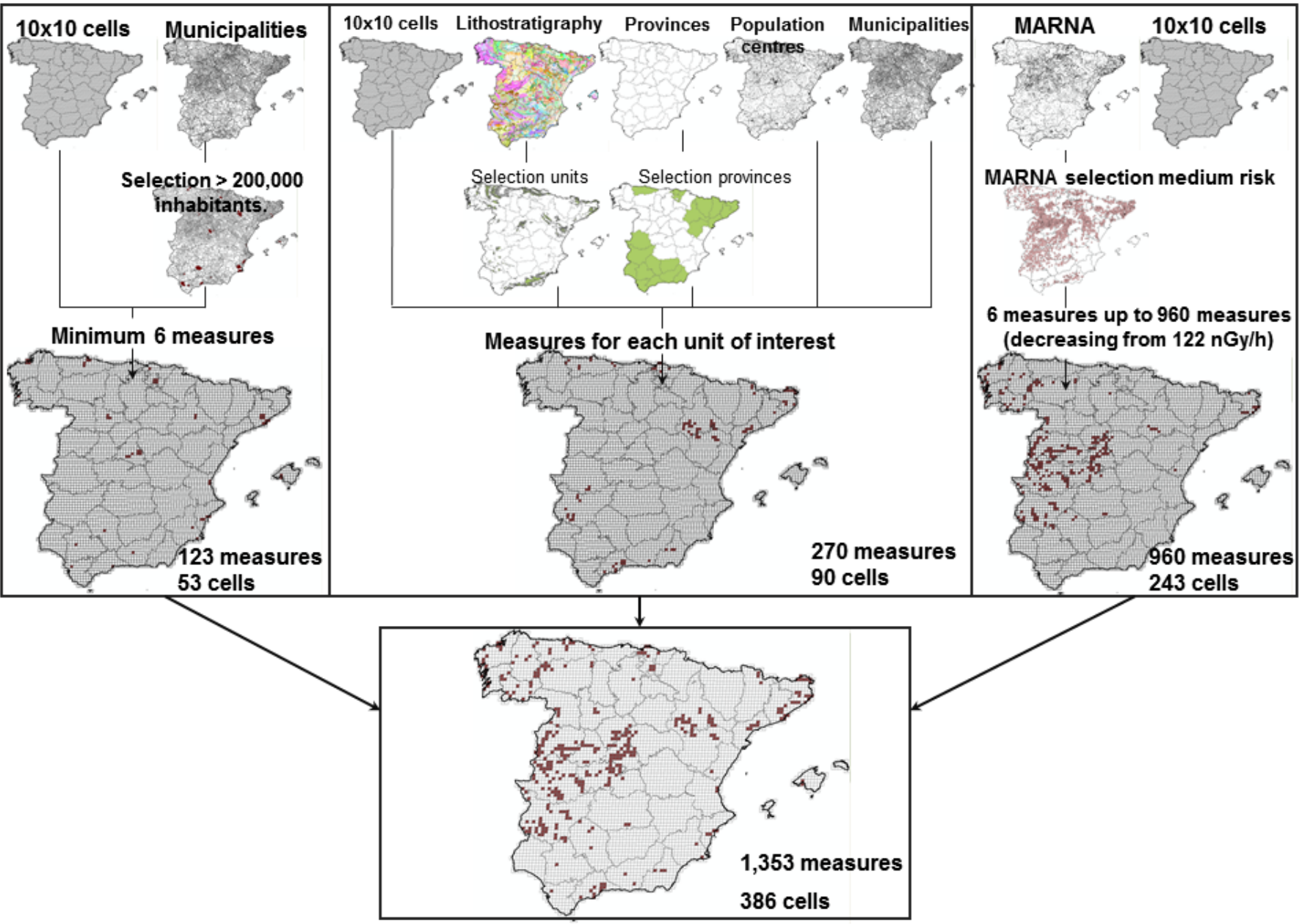

62 Figure 3 


\section{Identification of the locality and registration of detector}

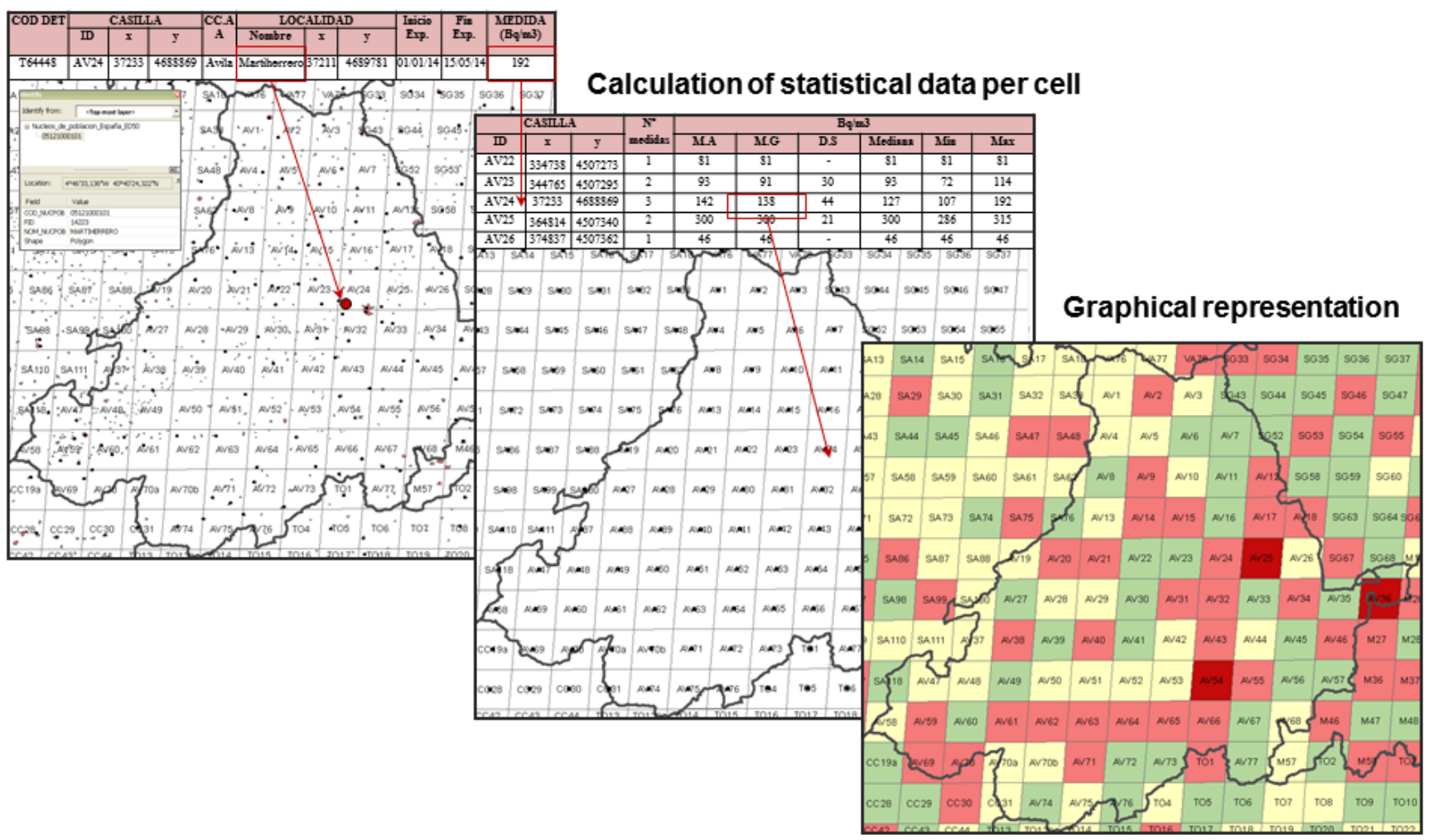

74 Figure 4 


\section{Distribution of measurements}

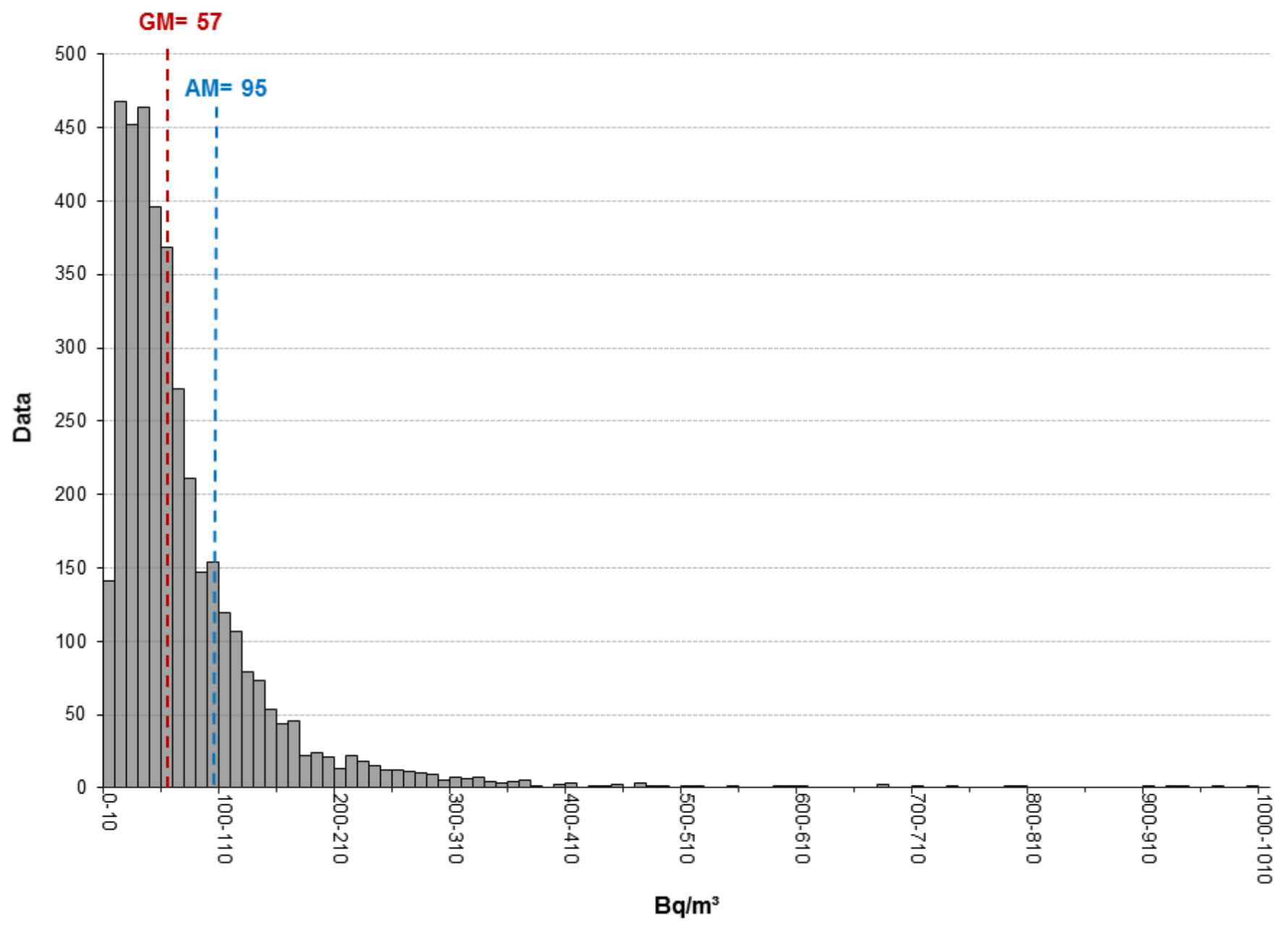

90 Figure 5

91

92

93

94

95

96

97

98

99

100 


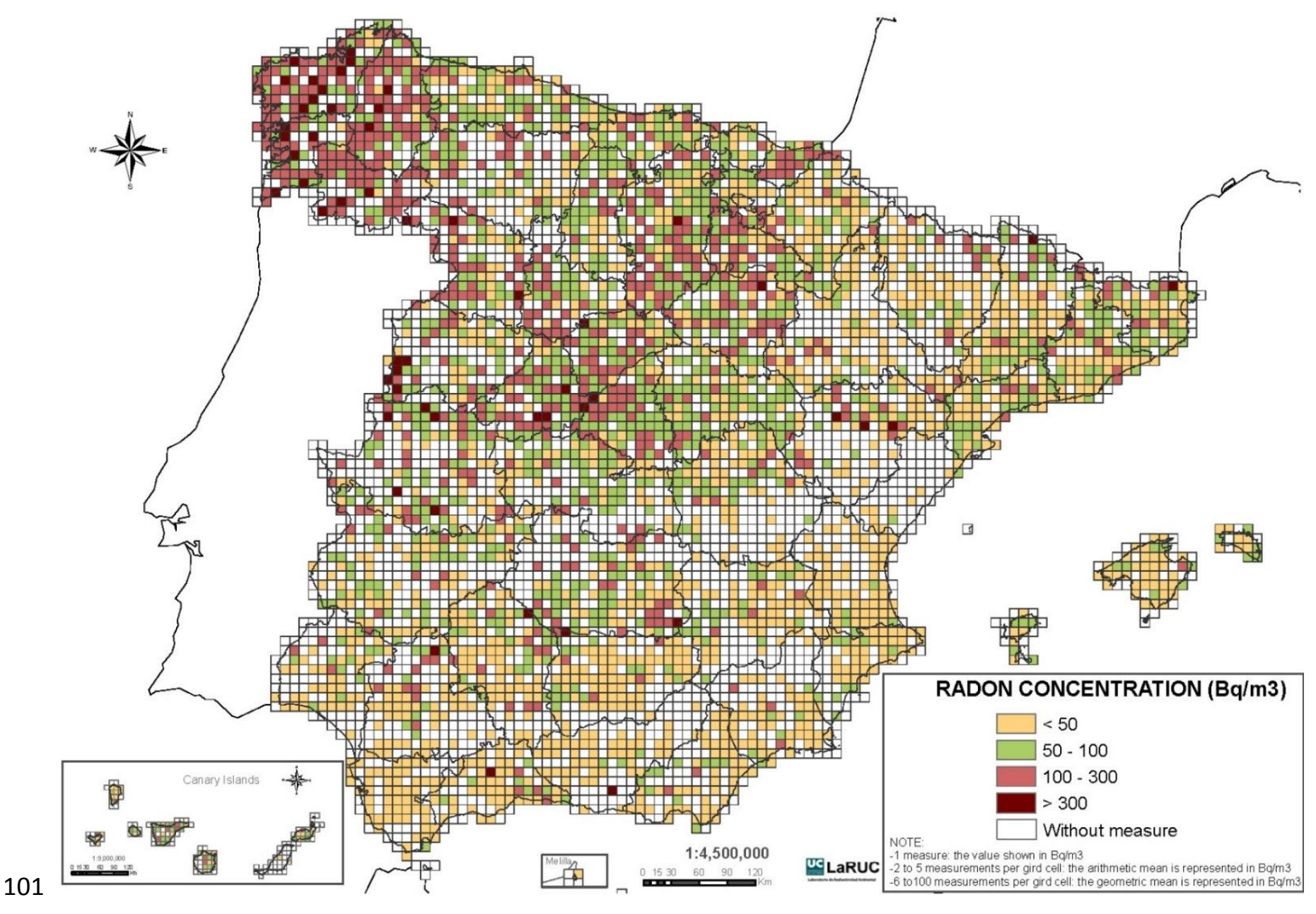

102 Figure 6

103

104

105

106

107

108

109

110

111

112

113

114 


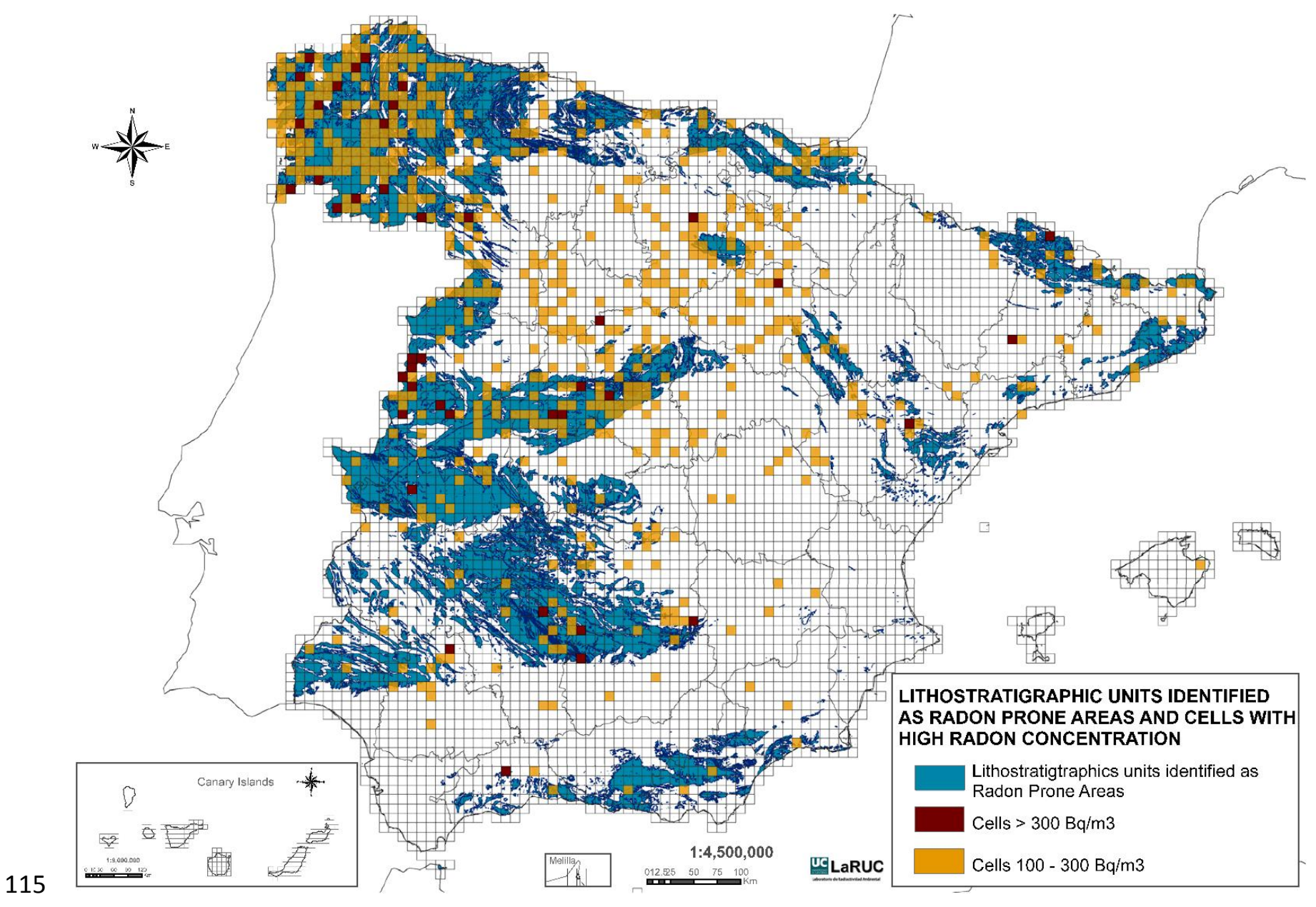

116 Figure 7

117

118

119

120

121

122

123

124

125

126

127

128 


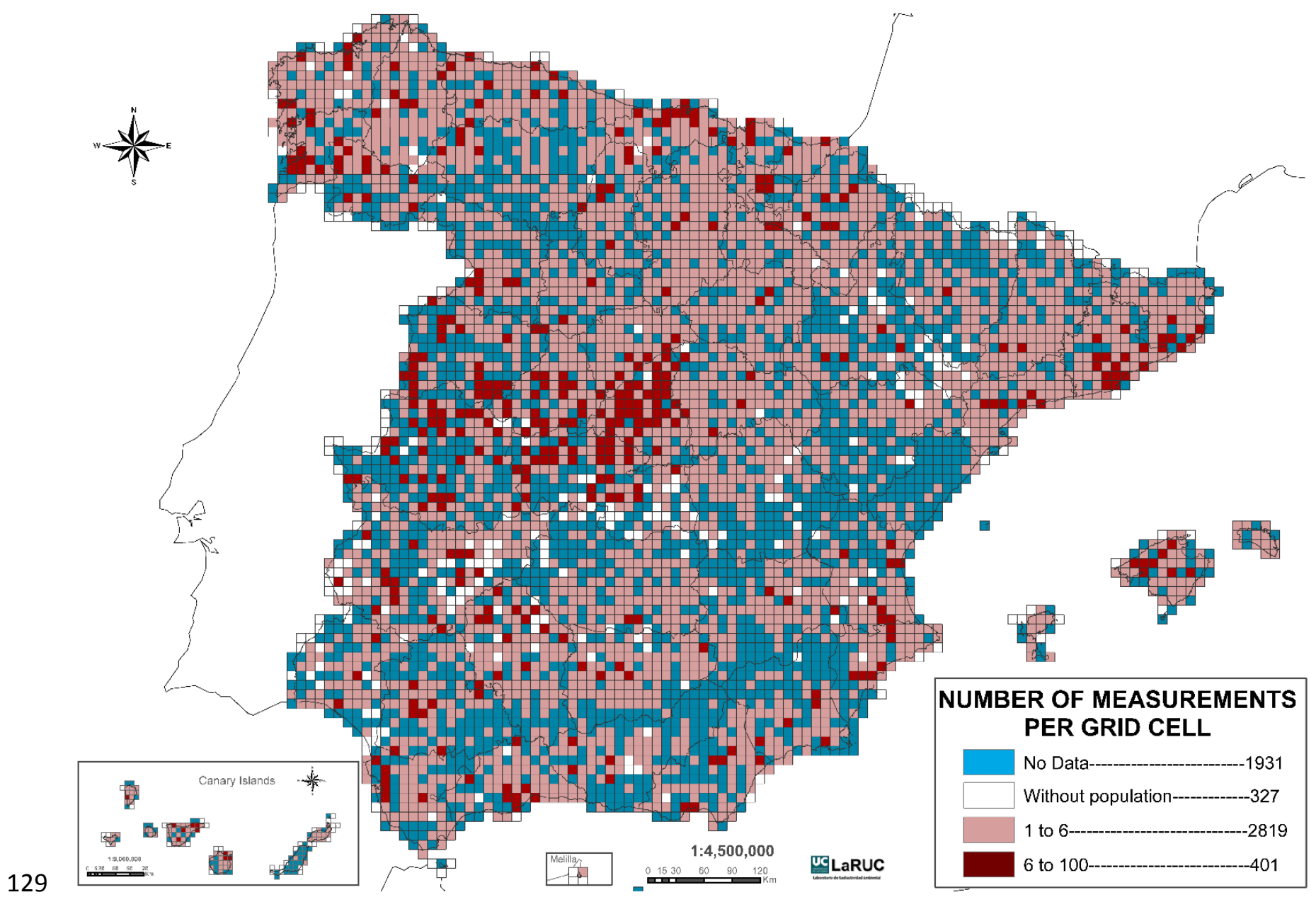

130 Figure 8

131

132 
Click here to download Table: 5.docx

1 Table 1: Reference systems using in the project: ED50 UTM Zone 30N and defined by the

2 European Commission (GISCO-LAEA)

Reference System

ED 1950 UTM Zone 30 N

\begin{tabular}{lll}
\hline Projection & Transverse Mercator & Lambert_Azimuthal_Equal_Area \\
\hline False Easting & 500000,000000 & 0,000000 \\
\hline False_Northing & 0,000000 & 0,000000 \\
\hline Central_Meridian & $-3,000000$ & 9,000000 \\
\hline Scale_Factor & 0,999600 & 48,000000 \\
\hline Latitude_Of_Origin & 0,000000 & Meter \\
\hline Linear Unit & Meter & GCS_ETRS_1989 \\
\hline GCS & GCS_European_1950 & Degree $(0,017453292519943299)$ \\
\hline Angular Unit & Degree (0,017453292519943299) & Greenwich $(0,00000000000000000)$ \\
\hline Prime Meridian & Greenwich (0,000000000000000) & GRS_1980 \\
\hline Spheroid & International_1924 & 6378137,000000000000000000 \\
\hline Semimajor Axis & 6378388,000000000000000000 & 6356752,314140356100000000 \\
\hline Semiminor Axis & 6356911,946127946500000000 & 298,257222101000020000
\end{tabular}

Reference System

GISCO-LAEA

3

4

5

6

7

8

9

10

11

12

13

14 
15 Table 2: Description of the spatial units of interest as used in this work and their lithostratigraphical 16 definition.

\section{Lithostratigraphic unit Lithostratigraphy definition \\ code}

(IGME)

$130 \quad$ Limestones, calcoschists and whiteboards

$131 \quad$ Micaschists, gneises, phyllites, quartzites and plasters

$133 \quad$ Micaschists, quartz and gneises

79 Slates, sandstone and quartzite. Series of los Cabos

$85 \quad$ Slates, sandstones and microconglomerates. Slates from Lancea

$86 \quad$ Quartzites, shales and rocks volcanocl. and volcanosed. Quartzite from Barrios and FM Oville

$91 \quad$ Slates and sandstones. Huergas slates

$104 \quad$ Quartzites, slates, sandstones, shales, limestones and dolomites.

Paleozoic Iberian Aragon

$117 \quad$ Quartzites and slates

Shales with interbedded carbonate and gypsum

7 Plutonic basic Hercinian rocks (gabbros, dioritas, tonalite, ultramafic rocks)

2 Acid rocks metamorphic (Otogneises,migmatitas). Gn. gland., metarriolitas (Ollo Sapo).

$127 \quad$ Phyllites, schists, quartzites, limestones, slates and corneal (metamorphic)

152 Sandstones, sands, sandy limestones, marls, clay and loamy

$153 \quad$ Sandstones, shales and marls 
17

18

19

20

21

22

23

24

25

26

27

28

29

30

31

32

33

34

35

36

37

38

39

40

41

42

43

44 
45 Table 3: Examples of the unit numbers of interest in some Spanish regions and the number of 46 measurements necessary to take. Not all Spanish regions are represented.

\begin{tabular}{llcl}
\hline Region & $\begin{array}{l}\text { Lithostratigraphic Measures to take } \\
\text { unit } \begin{array}{c}\text { code } \\
\text { interest (IGME) }\end{array}\end{array}$ & & \\
\hline Andalucía & $130-131-133$ & 40 & $\begin{array}{l}\text { In at least } 6 \text { different municipalities } \\
\text { (covering } 3 \text { units) with a minimum of } 6 \\
\text { measures by municipality }\end{array}$ \\
\hline Asturias & $79-85-86-91$ & 50 & $\begin{array}{l}\text { In at least } 8 \text { different municipalities } \\
\text { (covering } 4 \text { units) with a minimum of } 6 \\
\text { measures by municipality }\end{array}$ \\
\hline Aragón & $104-117-369$ & 40 & $\begin{array}{l}\text { In at least } 6 \text { different municipalities } \\
\text { (covering } 3 \text { units) with a minimum of } 6 \\
\text { measures by municipality }\end{array}$ \\
\hline Extremadura & 7 & & $\begin{array}{l}\text { In at least } 4 \text { different municipalities with a } \\
\text { minimum of } 6 \text { measures by municipality }\end{array}$
\end{tabular}

\begin{tabular}{|c|c|c|c|}
\hline Cataluña & 2-7-117-127 & 60 & $\begin{array}{l}\text { At least } 3 \text { municipalities in unit } 2,3 \\
\text { municipalities in unit } 7 \text { and } 3 \text { to } 117 \text { and } \\
127 \text { units. With a minimum of } 6 \text { measures } \\
\text { by municipality }\end{array}$ \\
\hline
\end{tabular}

País Vasco 152-153-173-174 $50 \quad$ In at least 8 different municipalities (covering 4 units) with a minimum of 6 measures by municipality 
59 Table 4: Concentration of radon: Number of cells and data

\begin{tabular}{ccc}
\hline $\begin{array}{c}\text { Range } \\
\left(\mathrm{Bq} / \mathrm{m}^{3}\right)\end{array}$ & Number of cells & Number of data \\
\hline$<50$ & $1606(29 \%)$ & $4294(46 \%)$ \\
\hline $50-100$ & $967(18 \%)$ & $2922(32 \%)$ \\
\hline $100-300$ & $602(11 \%)$ & $1902(21 \%)$ \\
\hline$>300$ & $42(1 \%)$ & $93(1 \%)$ \\
\hline
\end{tabular}

60

61

62

63

64

65

66

67

68

69

70

71

72

73

74

75

76

77

78

79

80 
81 Table 5: Number of measures per cell

\begin{tabular}{cc}
\hline $\begin{array}{c}\text { Number of measures } \\
(\text { Per cell) }\end{array}$ & Number of cells \\
No data & 41 \\
\hline 1 & 29 \\
\hline 2 & 12 \\
\hline 3 & 6 \\
\hline 4 & 3 \\
\hline 5 & 2 \\
\hline 6 to 100 & 7 \\
\hline
\end{tabular}

82

83

84

85

86

87

88

89

90

91

92

93

94

95

96

97

98

99

100

101

102

103

104

105

106 
107 Table 6: Descriptive statistics of data used to produce the Spanish indoor radon map up-to-date. ( $108 \mathrm{~Bq} / \mathrm{m}^{3}$ )

\begin{tabular}{ccccccc}
\hline $\begin{array}{c}\text { Number of } \\
\text { measurements }\end{array}$ & $\begin{array}{c}\text { Arithmetic } \\
\text { Mean }\end{array}$ & $\begin{array}{c}\text { Arithmetic } \\
\text { Standard } \\
\text { Deviation }\end{array}$ & $\begin{array}{c}\text { Geometric } \\
\text { Mean }\end{array}$ & $\begin{array}{c}\text { Geometric } \\
\text { Standard } \\
\text { Deviation }\end{array}$ & Median & RANGE \\
\hline 9,211 & 95.0 & 270 & 56.6 & 2.6 & 54 & $10-15,400$
\end{tabular}

109

110

111

112

113

114

115

116

117

118

119

120

121

122

123

124

125

126

127

128

129

130

131

132

133

134

135

136

137

138 
139 Table 7: Comparison on the effectiveness of different approaches to identify high radon risk areas.

140

\begin{tabular}{lccc}
\hline & $\begin{array}{c}\text { Lithostratigraphy } \\
\text { Scale 1:200,000 }\end{array}$ & $\begin{array}{c}\text { Lithology } \\
\text { Scale 1:1,000,000 }\end{array}$ & $\begin{array}{c}\text { Geology } \\
\text { Scale 1:1,000,000 }\end{array}$ \\
\hline All units & 329 & 26 & 16,041 \\
\hline $\begin{array}{l}\text { Units within radon } \\
\text { prone areas }\end{array}$ & 40 & 20 & 7,236 \\
\hline $\begin{array}{l}\text { Number of cell inside } \\
\text { radon prone areas }\end{array}$ & $>300 \mathrm{~Bq} / \mathrm{m}^{3} 37(88 \%)$ and $100-300 \mathrm{~Bq} / \mathrm{m}^{3} 421(70 \%)$ \\
\hline
\end{tabular}

141 
Histogram
Click here to download Supplementary Material: 20160420 rsw_histlog (1).pdf Click here to download Supplementary Material: 20160420 rsw_histlog (1).pdf

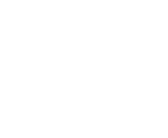
(1) (1) (1) (1) (1) (1)

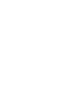
(1)

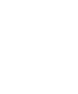

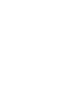
. . .

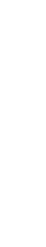
.

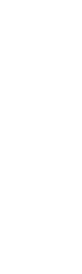

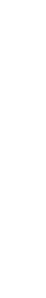

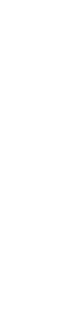

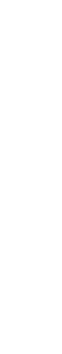
. . .

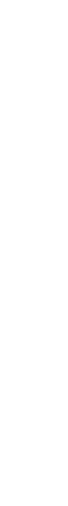

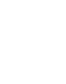
更 更 更 
Click here to download Supplementary Material: 20160420_rsw_qqplot (1).pdf

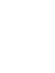

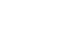
(1)

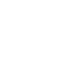
. . . . . . . . 
